\title{
Multimodal Technologies in Precision Education: Providing New Opportunities or Adding More Challenges?
}

\author{
Umar Bin Qushem ${ }^{1, *(\mathbb{D}}$, Athanasios Christopoulos ${ }^{1}$, Solomon Sunday Oyelere ${ }^{2} \mathbb{D}$, Hiroaki Ogata ${ }^{3}$ \\ and Mikko-Jussi Laakso ${ }^{1}$ \\ 1 Centre for Learning Analytics, Department of Computing, University of Turku, 20014 Turku, Finland; \\ atchri@utu.fi (A.C.); milaak@utu.fi (M.-J.L.) \\ 2 Department of Computer Science, Electrical and Space Engineering, Luleå University of Technology, \\ 97187 Luleå, Sweden; solomon.oyelere@ltu.se \\ 3 Academic Center for Computing and Media Studies, Kyoto University, Yoshidahonmachi, Sakyo Ward, \\ Kyoto 606-8501, Japan; hiroaki.ogata@gmail.com \\ * Correspondence: ubiqus@utu.fi
}

check for

updates

Citation: Qushem, U.B.;

Christopoulos, A.; Oyelere, S.S.;

Ogata, H.; Laakso, M.-J. Multimodal

Technologies in Precision Education:

Providing New Opportunities or

Adding More Challenges? Educ. Sci.

2021, 11, 338. https://doi.org/

10.3390/educsci11070338

Academic Editors: Rekha Koul and Gurpinder Singh Lalli

Received: 28 April 2021

Accepted: 30 June 2021

Published: 7 July 2021

Publisher's Note: MDPI stays neutral with regard to jurisdictional claims in published maps and institutional affiliations.

Copyright: (C) 2021 by the authors. Licensee MDPI, Basel, Switzerland. This article is an open access article distributed under the terms and conditions of the Creative Commons Attribution (CC BY) license (https:// creativecommons.org/licenses/by/ $4.0 /)$.

\begin{abstract}
Personalized or precision education (PE) considers the integration of multimodal technologies to tailor individuals' learning experiences based on their preferences and needs. To identify the impact that emerging multimodal technologies have on personalized education, we reviewed recent implementations and applications of systems (e.g., MOOCs, serious games, artificial intelligence, learning management systems, mobile applications, augmented/virtual reality, classroom technologies) that integrate such features. Our findings revealed that PE techniques could leverage the instructional potential of educational platforms and tools by facilitating students' knowledge acquisition and skill development. The added value of PE is also extended beyond the online digital learning context, as positive outcomes were also identified in blended/face-to-face learning scenarios, with multiple connections being discussed between the impact of PE on student efficacy, achievement, and well-being. In line with the recommendations and suggestions that supporters of PE make, we provide implications for research and practice as well as ground for policy formulation and reformation on how multimodal technologies can be integrated into the educational context.
\end{abstract}

Keywords: precision education; artificial intelligence; AI; multimodal technologies; technologyenhanced learning; personalized learning; smart learning environments; immersive technology; learning analytics; K-12 education

\section{Introduction}

One of the challenges that educational scholars and researchers attempt to address concerns the development of a better understanding of students' cognitive abilities and the underpinning factors that determine their learning strategies [1]. The artificial intelligence (AI) revolution has facilitated the attainment of the aforementioned goals with recent efforts discussing personalized learning paths starting from as early as primary education [2]. According to Pratt and Kovatcheva [3], the first step in achieving personalized education requires deconstructing the standardized curriculum into 'micro-lessons' with clearly defined competencies and assessment goals. The emphasis in the curricula breakdown makes incorporating personalized learning paths feasible and further promotes competence-based education (CBE) [4]. Chusni et al. [5] consider integrating diverse pedagogical approaches as the key in creating multilayered learning activities, whereas Martinez-Maldonado et al. [6] emphasize the importance of designing opportunities for multi-user interaction.

A proposed solution to the concerns mentioned earlier emerges after considering the approach that researchers from precision medicine follow, which aims to classify and treat disorders in a more personalized way [7]. Experts in other fields (e.g., psychology) have 
already welcomed this idea, arguing that the collection and interpretation of multimodal data can support developing a better understanding of the difficulties and challenges individuals face without speculating on subjective information [8].

However, even specialized study programs, with diligent examination and diagnostic evaluation from preliminary stages, lose their efficacy as students' requirements and abilities evolve [3]. The topics mentioned earlier, individually and collectively, raise questions regarding the forms of tutoring, counseling, or mentoring that the educator needs to provide and the motivational reinforcement and assistance level that instructional designers should offer learners to support their intellectual development.

'Precision' has brought significant improvements in many fields, with medicine being at the top of the list as patient treatment requires high accuracy and demanding throughput. When envisioning the potential of precision in education, it is crucial to consider the multidimensional nature of learning and the multilayered stages of instruction that students undergo. This is the essence of PE; the integration of diverse approaches to explore learning from multiple domains (e.g., psychology, sociology, science, engineering) so that individuals' learning difficulties can be identified. Therein, by drawing insights from the rigorous outcomes that have emerged from other disciplines (e.g., psychophysiology and biometrics, genetics and bioengineering), PE presents significant inquiries that connect individuals' biological attributes with their sociocultural background and other environmental factors $[9,10]$.

To this end, the so-called 'precision education' (PE) field emerged in view of researchers' inspiration to identify methods and techniques that can facilitate the diagnosis of learners' strengths and vulnerabilities so that more personalized or 'precise' support can be offered during the instructional process. Such practices are linked to digital (learning) tools that allow discovering hidden patterns related to the interplay between students' educational goals, motivation, attitude, and so on. However, educational technology integration constitutes only one of the many elements required to design and develop a 'personalized education' system.

In consideration of the above, we break down the components of the PE 'recipe' and align them to the scientific disciplines that can support such practices. The introduction of precision-oriented solutions-such as big data analytics and data mining-in the context of education has been translated as learning analytics and educational data mining, respectively [11]. Such methods are a powerful contributor to the identification of learners' characteristics and competencies. By adjusting the lens to the collection of 'intimate' information, the optical capability of the data structures is improved and facilitates the development of a more comprehensive framework related to learners' bio-profile [12]. Another sector is neuroscience, a highly valued discipline that enables researchers to acquire insights about the learning mechanisms that individuals utilize or the neuronal thinking patterns engaged during the learning process. Although neuroscience relies primarily on data emerging from neuroimaging (e.g., functional magnetic resonance imaging-fMRI, electroencephalography-EEG) to perform genomic and computational analysis, recent efforts have indicated that multimodal tools can provide a competitive alternative [13]. Educational psychology allows researchers to develop a deeper understanding of the learning process, including the reasons why students' performance fluctuates and the underlying links to their behavioral changes [14]. Finally, in recent years, the social problems that individuals encounter and the approaches used to handle them have been linked-both temporarily and spatially - to the element of opportunity. As a result, precise estimations cannot be guaranteed from the societal perspective but remain an evolving promissory horizon.

As we acknowledge that no specific educational approach or strategy fits the needs of all learners, we set the focus on the elements that should be considered when designing individualized learning scenarios and the approaches that can be utilized to determine learners' competencies and skills. Accordingly, we demonstrate the potential of customized educational services in providing precision learning and the respective benefits of adopting such practices on student efficacy, achievement, and well-being. The topics above are 
contextualized under the notion of multimodal technologies-as they present the potential to complement the information that digital learning systems harvest-and, collectively, support precise, versatile, and customizable educational directions.

\section{Theoretical Framework}

Education is one of the fundamental basic human rights. With the observed uprising evolution in every sector, education has also come into the spotlight, whereby impact and quality of experience are becoming the main focus points. The statement made by Rolf Reber et al. [15] pinpoints that there have been long-standing efforts in connecting students' learning with their personal life. Yet, while technology has made a significant contribution in the medicine sector (e.g., precision medicine) and the hospitality industry (customized order options), personalization in education has just begun.

Pengyu Gao [16] attempted to highlight the demand for precision education by posing a set of thoughtful yet provoking questions: "Can traditional education satisfy the industrialism?" "Can traditional education underscore the need for practical and creativity-based learning?" Such questions strengthen the reasons for which precision or personalized education is essential while also indicating the need to support pupils and youths in discovering their creative talents or entrepreneurial spirit.

Relevant efforts to identify the means or the methods that can support precision-based teaching and learning include skill-by-treatment interactions (STIs) in interventional studies [17], cognitive behavioral therapy (CBT) in view of identifying individuals' emotional needs [18], and integration of learning analytics and educational data mining techniques to improve pupils' academic performance and facilitate greater engagement [19].

Considering the infancy stage that this emerging concept is at, only a few empirical (domain-specific) studies can be identified and even fewer review efforts to synthesize and discuss their findings holistically. For instance, the studies conducted by Luan and Tsai [20] and Chen et al. [21] do not provide concrete examples of how personalized guidance (teachers' point of view) and precision learning (students' point of view) are linked to multimodal assessment. Likewise, the systematic review conducted by Zhang et al. [22] focuses explicitly on 'personalized learning' with the lens adjusted to the current spectrum of technology-enhanced education.

Motivated by the inadequacy of the literature to provide an all-inclusive report of the aforementioned topics, in this study, we set the focus on and discuss collectively both the idea that governs PE (therein, referring to precision teaching and learning) and the various multimodal technologies (tools, features) and instructional strategies that are already being used in the education sector. Therein, the research questions (RQs) that the study aims to investigate are as follows:

RQ1. How has precision education been viewed or integrated into schooling?

RQ2. How have multimodal technologies been facilitated the integration of precision education practices?

\section{Precision Education}

The term 'precision' is associated with the use of data to evaluate and manage a broad variety of phenomena [9]. Education researchers use common terminology (e.g., precision, customization, individualization, matching, tailoring) interchangeably to clarify the heterogeneity of individuals with specific difficulties so that they can administer targeted interventions with greater precision. This, in a sense, is the core of PE-to make efforts for the right person, to have the proper intervention in place for the right reason. In other words, precision scholars are not questioning whether an experiment is effective but, instead, they explore what interventions have been performed, for whom, and how.

The PE strategy can be broadly split into two sections: (a) precision teaching and (b) precision learning. Emerging areas of interest in personalized education involve the systematic usage of learner data to implement an individualized curriculum tailored to the learning activities. The steps required in achieving the latter concept can be paralleled 
with the 'navigational structure' that Google Maps utilizes. The first target is to help students comprehend the end-point learning goals (planned location). This includes the development of a clear understanding related to their current knowledge and competencies (current address) as well as the means to communicate their needs better (mode of transportation). Furthermore, guidance and assistance on how to build on the intermediate success opportunities (pathways to destination) must be disclosed.

Precision education is, by definition, relying on tremendous ambitions. This implies the convergence of genetics, neuroscience, behavioral, and psychological sciences exchanging viewpoints related to the learning process and deciding whether learning materials and tools can be integrated to support individuals' needs. This further explains why supporters of PE argue that to personalize the learning experience, advanced computer systems might be needed to process such massive amounts of data. Indeed, the provision of PE includes collecting extensive personal data, as indicated by the ongoing research efforts in genomics, psychology, and cognitive science, which explore both individuals' physiological conditions and the internal elements of their mind $[9,10]$.

It is assumed that the evolution of precision education began long before the spotlight was on Barak Obama's 2015 speech, as President of the USA, where he discussed different precision medicine initiatives [8] and their importance to the societal context $[8,10,23]$. Although there is debate regarding the origins of PE, examples of ways to support such practices include progress risk prediction and early warning using learning analytics. Moreover, the importance of PE has been observed in many contexts of teaching and learning. Lindsley, one of the early PE theorists, discovered and pinpointed from B.F. Skinner's experimental analysis of behavior the notion of precision teaching, identifying that "The Learner Knows Best", which inspired educators to contextualize it into an educational perspective [24,25]. The computer-based precision learning system for developing student fluency is an example of how contemporary artifacts may still be discovered [26].

In recent years, several educators and efforts have emerged to draw much needed retention for improvement in this sector. Stephen J. H. Yang of Taiwan National Central University identified four critical PE components related to PE: (a) diagnosis, (b) prognosis, (c) treatment, and (d) prevention [27]. Meanwhile, in the sociohistorical context of schooling, Professor Hiroaki Ogata of Kyoto University and his team's educational products were heavily influenced by the essence of PE where data from multivariate sources (e.g., digital logs, student psychiatric data from e-book systems) are utilized to improve K-12 students ${ }^{\prime}$ learning experiences across the country (Japan, Korea, Taiwan and Singapore) [28,29].

\section{Materials and Methods}

For the conduct of this literature review we employed the 'narrative approach' which can be defined as "a comprehensive synthesis of existing works that often discuss theory and context with the aim of provoking thought and controversy" [30]. In narrative reviews a qualitative approach is utilized wherein the findings of quantitative studies, that have employed various techniques or theoretical conceptualizations, are synthesized without focusing on the statistical significance of the outcomes [31,32]. A narrative method, as opposed to systematic literature reviews, depends more on informal processes for presenting and interpreting the literature, but it also has the ability to give readers a comprehensive overview and up-to-date information about the topic-related study field [33].

Considering the objective of this study, which is to shed light on the complex and diverse interrelationship between multimodal technologies and precision-based educational approaches, the narrative review method was deemed more appropriate due to its potential to facilitate the mapping of extensive and complicated study topics containing multiple issues such as the ones that relate to the context of education $[33,34]$. Therein, in the context of this study, the narrative review approach serves as a benchmark that helps to identify and understand the basics of the topic in question.

To attain the aforementioned objectives, a comprehensive keyword-based search was performed in databases streamlined toward the field of (educational) technology and the 
respective interdisciplinary subjects (Web of Science, Science Direct, EBSCO, ERIC, ACM Digital Library, IEEE Xplore, JSTOR, PsycINFO, Scopus, ProQuest). A manual search was also conducted in Google Scholar in accordance to the guidelines of the 'snowball sampling' research approach $[33,34]$.

To increase the range of the results, no filters were applied with regard to the publication source type (e.g., journal/conference manuscripts, book chapters) except for the language (English) and the publication timespan (from 1 January 2000 to 31 December 2020). The utilised keywords included a combination of the following key strings: "precision learning", "precise teaching", "personalized learning", "primary education", "secondary education", "K12", "higher education", "tertiary education".

The initial screening of the returned manuscripts $(n=2889)$ involved the examination of the titles, abstracts, and keywords. Shortlisted files $(n=499)$ were examined further and independently via the diagonal read-through approach. Upon completion of this process a total of 45 articles met the inclusion criteria. The manuscripts selected for detailed analysis and data extraction were divided across the readers in accordance with their field of expertise, which was carried out partially following the data extraction rubric adapted by Sharma and Giannakos [35]. The findings reported in the forthcoming sections constitute a synthesis of the research efforts that have been identified with a direct interest in facilitating $\mathrm{PE}$ and have been further enriched with distilled ideas for practice, policy and further research through reflection and multidisciplinary discourse.

\section{Results}

A wide range of potential benefits were identified in the data extracted from the relevant works (see Appendix A). Our attempts to articulate multimodal technologies and their integration in schooling would revitalize the sector of precision- or personalizationbased education. Several technologies have emerged to facilitate the concept of inclusive education. Multimodal tools constitute a typical example of how technology can mediate educational environments and support learners' individual needs. Under these considerations, we discuss how these technological aids can facilitate PE in the context of different Technology Enhanced Learning (TEL) solutions.

\subsection{Artificial Intelligence}

Students learn by thinking and listening, by observing and behaving, reasoning critically and intuitively, remembering and visualizing, drawing analogies, and constructing abstract structures. The notion of teaching and learning often applies in the physical context. However, the complementary use of digital and web-based AI-supported educational systems allows for the integration of assessments to determine student personality traits via diverse data collection methods and analytical approaches [36-38].

Although PE constitutes a new form of challenge in applied AI, the inception point of relevant efforts involves integrating widely adopted methods and techniques. For instance, to identify and classify students' learning styles [38], to forecast the probability of early dropouts [7], or to detect students' interactions with the provided web-based system [38], successful implementations report the use of the Bayesian Network approach. This probabilistic graphical model aids the classification of learners' behavioral traits (e.g., attitude, activity, intuition, sensitivity) and informs the clusters that display the different learning styles $[39,40]$.

\subsection{Educational Applications}

Fluency has long been recognized as a mandatory requirement for advanced performance in martial arts, music, and athletics [41] but was not widely embraced as a necessity for academic achievement [42]. However, progressing to the next stage without realizing a solid base to build upon creates a bottleneck in individuals' future development. While building on the criticism that relevant studies brought into the light by highlighting the difference between rote learning (i.e., memorization of information) and academic mastery 
(i.e., development of fluency or proficiency), a didactic shift was observed in educators' approaches. Instructors' efforts to support fluency development were materialized by integrating more cognitively challenging tasks-such as computational problem solving-as well as opportunities for reflection [43]. The outcomes of this change brought significantly positive results in students' future development and set the ground for a new didactic approach $[44,45]$.

Temple and Doerr [46] describe the interactional techniques that educators can utilize to improve students' computational competencies (fluency) via classroom discord led by the instructor. The evaluation results demonstrate positive outcomes in students' computational abilities and the acquisition of expressive skills. Another example of precision training for fluency development is discussed by Beck and Clement [47]. In this case, the target group was children with special needs, working together with their instructors, under the 'decision rule'. The approach used in this scenario implied that students could select the exercises they would like to perform, with the completion criteria being dynamically adjusting. By promoting high-achieving outcomes, students could advance through the curriculum sequence without feeling additional pressure.

Similarly, technology-enhanced learning (TEL) interventions aim at improving multiple competencies but with higher precision. For instance, the application for reading created by Germeroth and colleagues [48] enabled students to engage in activities that involve language learning supported by music. The idea behind this implementation lies in the ludic element that music brings in repetitive tasks and the relevant research which presents positive links to memory retention.

Pupils who develop good mathematical aptitude during the early stage of their childhood usually demonstrate improved academic achievements [49] and have better career advancement [50]. Connor et al. [51] examined the potential of the personalized curriculum in mathematics education via the Individualizing Student Learning in Mathematics (ISI-Math) program. In this longitudinal study, the ISI-Math tool was utilized to facilitate the instructional process via algorithm-based interventions and support students who struggle with diverse mathematical tasks. The evaluation outcomes revealed significantly better results in students' mathematical achievements and further illustrated the importance of technology in supporting daily instruction with high accuracy and precision [52]. Another field of application that PE has supported concerns the quality improvement of the teacher education programs and, more precisely, the equity across teachers' knowledge in mathematics. The study that Blömeke et al. [53] conducted revealed that the teacher education systems (e.g., USA, Taiwan, Singapore), which have inferred the strength of precision, have enabled mathematics instructors to apply various didactic methods which can help in identifying student misconceptions so that the provided feedback can be more appropriate and targeted to students' needs.

In the modern educational system, programming is one of the core subjects that promotes computational and reflective thinking skills [54]. Although these cognitive sectors have been widely explored, there are still many challenges and misconceptions that prevent novices from reaching their potential [55]. A proposed solution to tackle this issue has been the incorporation of programming courses into the curriculum of primary and secondary education to prepare students' analytical and computational mindset [56].

Finally, the collaborative digital tool ViLLE supports various educational subjects (programming, mathematics, languages), delivered via diverse instructional methods, which are automatically assessed [57]. For the time being, the platform is deployed in over 15 countries with more than 100.000 engaged stakeholders (teachers, students). The evaluation results demonstrate an increased degree of engagement as well as knowledge gains. This example sets the ground forward not only from the PE perspective but also from the potential of technology to support diverse learning outcomes without employing a large variety of tools. 


\subsection{Massive Open Online Courses}

Massive Open Online Courses (MOOCs), by acting as 'educational networks' which navigate students through specific 'paths' and 'routes', can act as precursors of 'course exemplars' [58]. Despite the initial idea that governed the design of MOOCs, their evolution and advancement has brought opportunities for providing learners with personalized learning experiences [59]. The first step to personalize the learning experience requires simplifying the learning material by 'graining' it into clearly defined units of information. By utilizing the backward design strategy, curriculum instructors can determine the educational objectives and adjust the assessment parameters according to the learners' needs and capabilities [60,61]. Moreover, the built-in curriculum planners and the communication tools that MOOC platforms offer can support the customization of the educational content and facilitate the interplay between the engaged stakeholders thus, making the personalization of the learning experience more optimal. In addition to these functionalities, recent implementations discuss the integration of features that involve the engagement of educators or community assistants [62] who aim at providing participants with either video feedback [63] or peer assessment [64]. From the users' perspective, the integration of rubrics for material reviews has also been found helpful in adjusting and personalizing the delivered content [65].

\subsection{Serious Games}

Student motivation is considered to be one of the most reliable indicators to predict future academic performance. However, educational researchers and scholars have made intense criticism of the conventional schooling system for being weak in motivating learners [66]. Supporters of educational or serious games promote immersive learning wherein the student-users reach a state of deep learning that enables them to conceptualize, process, and reflect on the subjects under investigation [67]. The foundations of the gamebased learning approach rely on the essence that learning can also occur subconsciously, whereas the learning experience and the incentives for engagement are further enhanced with elements that have been initially introduced in leisure games (e.g., quests, trophies, competition). Such elements have been positively correlated, in multiple studies, with increased motivational interest (i.e., engagement) and ultimately better outcomes in learning performance [68-72].

Although the settings of the (educational) games may vary, their norms are framed under the same concept, that is, to engage users in interesting (learning) activities via which they can either experience the premade storyline or even shape their decisions. For instance, in the digital game Rise of Nations, players need to consider and critically evaluate how their present actions will shape the future evolution of their civilization and their impact on the progression of other players [69]. Another successful application of computer games in education is the provision of learning paradigms [70]. For example, the single-player educational game Immune Attack integrates realistic 3D models of cells and molecules with interactive capabilities, allowing users to 'navigate' through the human body and observe how the immune system is reacting to different viral and bacterial invasions [73].

The potential impact that leisure or educational games may have on learning has received ample attention, with arguments claiming that girls may not be interested in playing video games or, otherwise, be engaged for as long as boys may be. Nevertheless, such viewpoints lack evidence emerging from systematic and empirical studies [68], whereas Carr [74] further adds that priorities have nothing to do with exposure to or experience with gaming. Jovanovic et al. [75] suggest that gamified educational scenarios can be satisfying if the experience is optimally personalized with elements that evoke both leisure and inspiration. To achieve this balance, the authors further recommend integrating multimodal interactions as the primary mechanism for conveying instructional content. 'VStrat' is an indicative example of an educational game with personalized learning elements wherein learners' emotional states are distinguished and profiled according to their abilities and interests [75]. 
Adaptive educational games provide a motivating learning environment that is reinforced with a personalized learning experience which ensures that the learner takes charge of the learning process. In recent times, artificial intelligence techniques have played a key role in realizing adaptivity features in educational games, including areas such as path finding, role-playing elements, adaptive game engine, macro-adaptivity, dynamic difficulty adjustment, non-player character's behavior, adaptation of challenge ordering and selection [72,76-79]. The ELEKTRA game [80] is an example of the application of serious game in the context of personalized learning. ELEKTRA focuses on assessment and adaptation in a 3D adventure game. The non-player characters (NPCs) provide the students with learning and motivational guidance through situation adaptive problem-solving support and meta-cognitive feedback [80].

\subsection{Mobile Applications and e-Books}

Integrated technologies like smartphones, tablets, and other portable computing gadgets may have not emerged with the educational aspect in mind but provide ample opportunities for precision digital learning. Mobile learning applications supports general, collaborative, and social aspects of learning in different contexts [81,82]. Besides, smart mobile learning environments are adaptive and context-aware, ensuring personalized and easy access to learning activities [83]. Relevant efforts are based on the wide acceptance that mobile educational applications have received and the transition from books to ebooks. For instance, the BookRoll application was designed in line with the seamless and ubiquitous learning principles so that students can have unrestricted access to the reading material while instructors can evaluate any reading inefficiencies through the browsing logs $[28,84]$ whereas, the SCROLL application extended the effort as mentioned earlier further by providing opportunities for analytics related to the users' interactions and gradual progression [85].

E-books tend to be more versatile than their predecessors, thanks to the enriched aesthetic multimedia effects they offer and the numerous options for personalization and customization. Although several studies have examined the educational potential of ebooks in higher education, the adoption of such practice has received significantly less consideration in primary or even secondary education. Motivated by this shortcoming, Huang et al. [86] took the initiative to develop an exemplary infrastructure that could support the design of immersive e-books after accounting for the challenges [87] and the limited options [88] that students of such age groups face and have, respectively. By integrating elements that could assist learners in expanding their reading and comprehension skills in an inclusive and precise way, this initiative was not only welcomed by the respective research community but also set the ground for the development of additional features and elements which could help in bridging the gap between learners' current level of knowledge and skills.

\subsection{Immersive Technologies}

The technological evolution has enabled individuals to produce and access information without any spatiotemporal limitations [89]. The initial emergence of computergenerated (artificial) multimedia environments, such as virtual reality (VR) and augmented reality (AR), introduced a new form of information sharing while also making the available content more intuitive and appealing for the end-users [90-92]. Despite the never-ending debates concerning the application of such solutions in the consumer market, the integration of VR in education has demonstrated significant benefits [93-95].

Pellas et al. [96] list the various benefits that the integration of VR has brought in education with particular reference to the opportunities for interaction that the 3D simulated content offers while disseminating the respective information readily available. Wang et al. [97] discuss the integration of various pedagogical approaches in AR-based applications and further elaborate on the elements that make such learning experiences more attractive and effective. 
Studies $[98,99]$ that have investigated the impact of VR and AR technologies in education have identified various benefits related to knowledge acquisition, commitment, motivation, and academic achievement. The added value of this alternative educational approach is usually attributed to the high representational fidelity of the three-dimensional (3D) virtual objects and the opportunity offered to learners to simulate operations and procedures of abstract concepts $[100,101]$. An indicative example of such integration is the Simodont application which can be utilized in dental education [102]. Simodont combines various features that facilitate the in-depth exploration of the subject under investigation and haptic, visual, and textual feedback.

Opportunities for personalized learning are also identified in the broader context of the interplay that users (learners) have with the virtual content, which includes but is not limited to exploration, simulations (performance), and active participation in hands-on activities [103]. A typical example of such a tool for personalized learning is the SMART (System of Augmented Reality for Teaching) application that Freitas and Campos [104] designed. SMART can be utilized to teach children information about different everyday objects and types of animals using real-time videos. The evaluation results revealed that during the video playtime, children's attention was as concentrated as when playing video games. Based on these findings, an implication was made that such tools can be utilized in the physical classroom to cultivate students' interest and learning motivation. An example of VR application in education is the Imikode VR learning game, which facilitate the teaching and learning of object-oriented programming concepts in an immersive and engaging way. Imikode was developed and operates with Google Cardboard, Unity 3D, and smartphones [76].

\subsection{Classroom Technologies}

The reform of the academic curriculum under the aid of modern technologies and the introduction of the hybrid teaching approach has achieved unprecedented success in influencing students' attitudes toward education. The Cloud Classroom is one of the most recent initiatives that support the idea of free education by providing a network of teaching and learning tools based on the cloud computing approach [105]. In view of PE, the Cloud Classroom enables educators to share educational resources and individuals to access the learning material without any restrictions or constraints [106]. In addition, the model provides an innovative alternative to Google Docs through which learners can engage in a collaborative writing cycle (i.e., role allocation, brainstorming, action scheduling, updating, editing, revising) and receive feedback from the partner educators [107].

A wide variety of potential features were identified in the data extracted from relevant studies, which are represented in Table 1, with the remainder of the potential precision-wise yet multidisciplinary aspects listed in the Table A1 (see Appendix A).

Table 1. Summary of multimodal technologies have facilitated the integration of precision education practices.

\begin{tabular}{|c|c|c|c|c|c|c|}
\hline No & Reference & Tools & Area & Pedagogy & Multimodality Features & $\begin{array}{l}\text { Precision Education } \\
\text { (Context) }\end{array}$ \\
\hline [13] & $\begin{array}{l}\text { Williamson } \\
(2019)\end{array}$ & $\begin{array}{l}\text { Big data analysis } \\
\text { and machine } \\
\text { learning }\end{array}$ & $\begin{array}{l}\text { Artificial } \\
\text { intelligence }\end{array}$ & $\begin{array}{l}\text { Digital data- } \\
\text { processing-based } \\
\text { solutions }\end{array}$ & $\begin{array}{l}\text { psychological states, } \\
\text { genetic identities, and } \\
\text { brain activity }\end{array}$ & $\begin{array}{l}\text { Development of } \\
\text { data-intensive policy, } \\
\text { sociology }\end{array}$ \\
\hline [11] & $\begin{array}{l}\text { Williamson } \\
\text { (2017) }\end{array}$ & $\begin{array}{l}\text { Big data and data } \\
\text { mining }\end{array}$ & $\begin{array}{l}\text { Artificial } \\
\text { intelligence }\end{array}$ & $\begin{array}{l}\text { Learning-analytics- } \\
\text { based } \\
\text { solutions }\end{array}$ & $\begin{array}{l}\text { Daily activities including } \\
\text { user behaviors, } \\
\text { preferences, tastes, usage } \\
\text { of social media, }\end{array}$ & $\begin{array}{l}\text { Identification of learners' } \\
\text { characteristics and } \\
\text { competencies }\end{array}$ \\
\hline [23] & $\begin{array}{l}\text { Wartman and } \\
\text { Combs (2018). }\end{array}$ & $\begin{array}{l}\text { Intelligent agents } \\
\text { and robots }\end{array}$ & $\begin{array}{l}\text { Artificial } \\
\text { intelligence }\end{array}$ & $\begin{array}{l}\text { Machine-based } \\
\text { analysis and } \\
\text { decision-support } \\
\text { based AI } \\
\text { application }\end{array}$ & $\begin{array}{l}\text { Healthcare, biomedical, } \\
\text { and clinical data sources }\end{array}$ & $\begin{array}{l}\text { Reformation of medical } \\
\text { education industry and } \\
\text { practices }\end{array}$ \\
\hline [7] & $\begin{array}{l}\text { Tsai et al. } \\
(2020)\end{array}$ & $\begin{array}{l}\text { Statistical learning } \\
\text { and deep learning }\end{array}$ & $\begin{array}{l}\text { Artificial } \\
\text { intelligence }\end{array}$ & $\begin{array}{l}\text { Method-based } \\
\text { interventions }\end{array}$ & $\begin{array}{l}\text { Behavioral, background } \\
\text { information, } \\
\text { performance records }\end{array}$ & $\begin{array}{l}\text { Identification of learning } \\
\text { failure and determinants of } \\
\text { performance }\end{array}$ \\
\hline
\end{tabular}


Table 1. Cont.

\begin{tabular}{|c|c|c|c|c|c|c|}
\hline No & Reference & Tools & Area & Pedagogy & Multimodality Features & Precision Education (Context) \\
\hline [38] & $\begin{array}{l}\text { García et al. } \\
\text { (2007) }\end{array}$ & $\begin{array}{l}\text { Bayesian networks } \\
\text { (AI) }\end{array}$ & $\begin{array}{l}\text { Artificial } \\
\text { intelligence }\end{array}$ & $\begin{array}{l}\text { Web-based } \\
\text { education }\end{array}$ & $\begin{array}{l}\text { Student behavior: } \\
\text { learning styles }\end{array}$ & $\begin{array}{l}\text { Detection of student different } \\
\text { dimension of learning styles }\end{array}$ \\
\hline [65] & $\begin{array}{l}\text { Stevens and } \\
\text { Levi (2013) }\end{array}$ & Rubrics & $\begin{array}{l}\text { Educational } \\
\text { application }\end{array}$ & $\begin{array}{l}\text { Assessment-based } \\
\text { learning; } \\
\text { feedback-based } \\
\text { learning }\end{array}$ & $\begin{array}{l}\text { Learning and teaching } \\
\text { information }\end{array}$ & $\begin{array}{l}\text { Facilitating student learning } \\
\text { assessment in different } \\
\text { situations }\end{array}$ \\
\hline [57] & $\begin{array}{l}\text { Laakso et al. } \\
(2020)\end{array}$ & $\begin{array}{l}\text { ViLLE learning } \\
\text { platform }\end{array}$ & $\begin{array}{l}\text { Educational } \\
\text { application }\end{array}$ & $\begin{array}{l}\text { Feedback-based } \\
\text { learning assessment }\end{array}$ & $\begin{array}{l}\text { Student performances } \\
\text { data }\end{array}$ & $\begin{array}{l}\text { Supporting different learning } \\
\text { and improving student } \\
\text { performance }\end{array}$ \\
\hline [54] & Durak (2020) & $\begin{array}{l}\text { Scratch and Alice } \\
\text { tools }\end{array}$ & $\begin{array}{l}\text { Educational } \\
\text { application }\end{array}$ & $\begin{array}{l}\text { Technology- } \\
\text { enhanced } \\
\text { learning }\end{array}$ & $\begin{array}{l}\text { Multimedia objects, } \\
\text { drawing images, } \\
\text { recorded sounds }\end{array}$ & $\begin{array}{l}\text { Programming teaching } \\
\text { practices on student } \\
\text { engagement, reflective thinking, } \\
\text { problem-solving skills, and } \\
\text { computational thinking }(\mathrm{CT})\end{array}$ \\
\hline [107] & $\begin{array}{l}\text { Calvo et al. } \\
(2010)\end{array}$ & iWrite & $\begin{array}{l}\text { Educational } \\
\text { application }\end{array}$ & $\begin{array}{l}\text { Computer- } \\
\text { supported } \\
\text { collaborative } \\
\text { learning }\end{array}$ & $\begin{array}{l}\text { Intelligent automatic } \\
\text { feedback, automatic } \\
\text { question generation }\end{array}$ & $\begin{array}{l}\text { Managing collaborative and } \\
\text { individual writing assignments } \\
\text { in large cohorts }\end{array}$ \\
\hline [39] & $\begin{array}{l}\text { Commons et al. } \\
(2015)\end{array}$ & $\begin{array}{l}\text { Model of } \\
\text { Hierarchical } \\
\text { Complexity (MHC) }\end{array}$ & $\begin{array}{l}\text { Educational } \\
\text { application }\end{array}$ & $\begin{array}{l}\text { Technology- } \\
\text { enhanced } \\
\text { program }\end{array}$ & $\begin{array}{l}\text { Sensory, motor, } \\
\text { sentimental, } \\
\text { perceptional }\end{array}$ & $\begin{array}{l}\text { Performance and behavioral } \\
\text { analysis }\end{array}$ \\
\hline [105] & Chen (2019) & Cloud Classroom & $\begin{array}{l}\text { Classroom } \\
\text { technology }\end{array}$ & $\begin{array}{l}\text { Application-based } \\
\text { hybrid teaching }\end{array}$ & Student learning data & $\begin{array}{l}\text { Data-driven knowledge and } \\
\text { curriculum construction }\end{array}$ \\
\hline [51] & $\begin{array}{l}\text { Connor et al. } \\
(2018)\end{array}$ & ISI-Math Program & $\begin{array}{l}\text { Classroom } \\
\text { technology }\end{array}$ & $\begin{array}{l}\text { Classroom-based } \\
\text { intervention }\end{array}$ & $\begin{array}{l}\text { Math fluency standard } \\
\text { scores, vocabulary scores }\end{array}$ & Math fluency development \\
\hline [48] & $\begin{array}{l}\text { Germeroth } \\
\text { et al. (2018) }\end{array}$ & Lyrics2Learn & $\begin{array}{l}\text { Classroom } \\
\text { technology }\end{array}$ & $\begin{array}{l}\text { Classroom-based } \\
\text { intervention }\end{array}$ & $\begin{array}{l}\text { Perceptions, phonemic } \\
\text { awareness, alphabet } \\
\text { principle, accuracy and } \\
\text { fluency with connected } \\
\text { text, reading } \\
\text { comprehension, and } \\
\text { vocabulary }\end{array}$ & $\begin{array}{l}\text { Innovation to facilitate reading } \\
\text { disparities and language } \\
\text { learning }\end{array}$ \\
\hline [10] & $\begin{array}{l}\text { Kuch et al. } \\
(2020)\end{array}$ & $\begin{array}{l}\text { Neuroscience: } \\
\text { Functional } \\
\text { magnetic resonance } \\
\text { imaging or } \\
\text { functional MRI } \\
\text { (fMRI) and Elec- } \\
\text { troencephalography } \\
\text { (EEG) }\end{array}$ & $\begin{array}{l}\text { Classroom } \\
\text { technology }\end{array}$ & $\begin{array}{l}\text { Classroom-based } \\
\text { practice }\end{array}$ & $\begin{array}{l}\text { Students' effects, bodies, } \\
\text { brains, genetics, } \\
\text { cognition }\end{array}$ & $\begin{array}{l}\text { Implementation of } \\
\text { individualized practices and } \\
\text { targeted learning }\end{array}$ \\
\hline [85] & $\begin{array}{l}\text { Mouri et al. } \\
(2018)\end{array}$ & SCROLL & $\begin{array}{l}\text { e-Book } \\
\text { technology }\end{array}$ & $\begin{array}{l}\text { Learning-analytics- } \\
\text { based Ubiquitous } \\
\text { Learning System } \\
\text { learning system }\end{array}$ & $\begin{array}{l}\text { Learning and } \\
\text { operational logs (book } \\
\text { opening, zooming, } \\
\text { bookmarking, memo, } \\
\text { words searching, words } \\
\text { highlighting, and page } \\
\text { turning) }\end{array}$ & $\begin{array}{l}\text { Supporting Seamless Language } \\
\text { Learning through e-books }\end{array}$ \\
\hline [84] & $\begin{array}{l}\text { Chen and Su } \\
\text { (2019) }\end{array}$ & $\begin{array}{l}\text { BookRoll E-book } \\
\text { reading system }\end{array}$ & $\begin{array}{l}\text { e-Book } \\
\text { technology }\end{array}$ & $\begin{array}{l}\text { Moodle-based } \\
\text { embedded system }\end{array}$ & $\begin{array}{l}\text { "Reading behaviors: } \\
\text { bookmarking, } \\
\text { adding-deleting } \\
\text { markers, attaching- } \\
\text { removing-editing } \\
\text { memos, and slide } \\
\text { switching (jumping } \\
\text { page)" }\end{array}$ & $\begin{array}{l}\text { Evaluation of self-regulated } \\
\text { learning, self-efficacy, and } \\
\text { academic achievement }\end{array}$ \\
\hline [86] & $\begin{array}{l}\text { Huang et al. } \\
(2012)\end{array}$ & $\begin{array}{l}\text { E-book-based } \\
\text { learning system }\end{array}$ & $\begin{array}{l}\text { e-Book } \\
\text { technology }\end{array}$ & $\begin{array}{l}\text { Technology- } \\
\text { enhanced learning } \\
\text { and mobile-based } \\
\text { learning }\end{array}$ & $\begin{array}{l}\text { E-annotation and } \\
\text { bookmarks, content } \\
\text { searching, and learning } \\
\text { process tracking }\end{array}$ & $\begin{array}{l}\text { Empowering mobile } \\
\text { personalized learning }\end{array}$ \\
\hline [103] & $\begin{array}{l}\text { Fonseca et al. } \\
(2014)\end{array}$ & Augmented reality & $\begin{array}{l}\text { Immersive } \\
\text { technology }\end{array}$ & $\begin{array}{l}\text { Assessment-based } \\
\text { learning }\end{array}$ & $\begin{array}{l}\text { User profile test, } \\
\text { motivations, academic } \\
\text { performance }\end{array}$ & $\begin{array}{l}\text { AR technology in the } \\
\text { visualization of 3D models and } \\
\text { the presentation of architectural } \\
\text { projects }\end{array}$ \\
\hline [104] & $\begin{array}{l}\text { Freitas and } \\
\text { Campos (2008) }\end{array}$ & SMART & $\begin{array}{l}\text { Immersive } \\
\text { technology }\end{array}$ & $\begin{array}{l}\text { Augmented-reality- } \\
\text { based education } \\
\text { system }\end{array}$ & $\begin{array}{l}\text { Learning concepts, video } \\
\text { feed, TV show }\end{array}$ & $\begin{array}{l}\text { Teaching second-grade } \\
\text { students with AR smart system }\end{array}$ \\
\hline [70] & Mayo (2007) & $\begin{array}{l}\text { Immersive game } \\
\text { technology }\end{array}$ & $\begin{array}{l}\text { Immersive } \\
\text { technology }\end{array}$ & $\begin{array}{l}\text { Experimental and } \\
\text { inquiry-based } \\
\text { learning }\end{array}$ & $\begin{array}{l}\text { Learning outcome data } \\
\text { from gaming } \\
\text { environment }\end{array}$ & $\begin{array}{l}\text { Allowing interactive lectures, } \\
\text { experiments, observations, and } \\
\text { teacher demonstrations }\end{array}$ \\
\hline
\end{tabular}


Table 1. Cont.

\begin{tabular}{|c|c|c|c|c|c|c|}
\hline No & Reference & Tools & Area & Pedagogy & Multimodality Features & Precision Education (Context) \\
\hline [76] & $\begin{array}{l}\text { Bouali et al. } \\
\text { (2019) }\end{array}$ & Imikode & $\begin{array}{l}\text { Immersive } \\
\text { technology }\end{array}$ & $\begin{array}{l}\text { Virtual-reality- } \\
\text { based learning, } \\
\text { game-based } \\
\text { learning }\end{array}$ & $\begin{array}{l}\text { Unity 3D, Android SDK, } \\
\text { Google Cardboard, } t \\
\text { headset and Bluetooth } \\
\text { controller }\end{array}$ & $\begin{array}{l}\text { Supporting teaching and } \\
\text { learning of object-oriented } \\
\text { programming (OOP) concepts }\end{array}$ \\
\hline [102] & $\begin{array}{l}\text { Wang et al. } \\
\text { (2016) }\end{array}$ & $\begin{array}{l}\text { 3D haptic virtual } \\
\text { reality simulation }\end{array}$ & $\begin{array}{l}\text { Immersive } \\
\text { technology }\end{array}$ & $\begin{array}{l}\text { Virtual-reality- } \\
\text { based } \\
\text { assessment }\end{array}$ & $\begin{array}{l}\text { Crown preparation tasks } \\
\text { and outcome, recording } \\
\text { of elapsed time for } \\
\text { preparation }\end{array}$ & $\begin{array}{l}\text { Training dental crown } \\
\text { preparation in dental preclinical } \\
\text { education }\end{array}$ \\
\hline [100] & $\begin{array}{l}\text { Christopoulos } \\
\text { et al. (2014) }\end{array}$ & $\begin{array}{l}\text { OpenSim-based } \\
\text { Virtual World }\end{array}$ & $\begin{array}{l}\text { Immersive } \\
\text { technology }\end{array}$ & $\begin{array}{l}\text { Virtual-reality- } \\
\text { based collaborative } \\
\text { learning }\end{array}$ & $\begin{array}{l}\text { User-to-user and } \\
\text { user-to-world } \\
\text { interactions, learning } \\
\text { activities, student } \\
\text { engagement }\end{array}$ & $\begin{array}{l}\text { Hybrid model of education } \\
\text { with and within a virtual world }\end{array}$ \\
\hline [90] & $\begin{array}{l}\text { Christopoulos } \\
\text { et al. (2018) }\end{array}$ & $\begin{array}{l}\text { Hybrid Virtual } \\
\text { Learning (HVL) } \\
\text { models }\end{array}$ & $\begin{array}{l}\text { Immersive } \\
\text { technology }\end{array}$ & $\begin{array}{l}\text { Virtual-reality- } \\
\text { based collaborative } \\
\text { learning }\end{array}$ & $\begin{array}{l}\text { Student awareness, } \\
\text { direct cognition, } \\
\text { interaction between } \\
\text { students and virtual } \\
\text { worlds }\end{array}$ & $\begin{array}{l}\text { Improvising higher levels of } \\
\text { student engagement }\end{array}$ \\
\hline [97] & $\begin{array}{l}\text { Wang et al. } \\
\text { (2018) }\end{array}$ & Augmented reality & $\begin{array}{l}\text { Immersive } \\
\text { technology }\end{array}$ & $\begin{array}{l}\text { Wearable- } \\
\text { technology-based } \\
\text { learning }\end{array}$ & $\begin{array}{l}\text { Video, learner } \\
\text { interactions, IoT, } \\
\text { brainwave and sensory } \\
\text { data }\end{array}$ & $\begin{array}{l}\text { Bringing immersive } \\
\text { experiences between people } \\
\text { and businesses through } \\
\text { communication }\end{array}$ \\
\hline [9] & $\begin{array}{l}\text { Williamson } \\
(2018)\end{array}$ & $\begin{array}{l}\text { Neurotechnology } \\
\text { (neuroheadsets) and } \\
\text { psychometric } \\
\text { measures }\end{array}$ & $\begin{array}{l}\text { Immersive } \\
\text { technology }\end{array}$ & $\begin{array}{l}\text { Wearable-enhanced } \\
\text { learning }\end{array}$ & $\begin{array}{l}\text { Neurological, genetic, } \\
\text { psychological, and } \\
\text { behavioral data along } \\
\text { with environmental } \\
\text { factors }\end{array}$ & $\begin{array}{l}\text { Intimate data analytics: } \\
\text { scientific knowledge, technical } \\
\text { innovation, business plans, and } \\
\text { social or political motivations }\end{array}$ \\
\hline [83] & $\begin{array}{l}\text { Agbo and } \\
\text { Oyelere (2019) }\end{array}$ & $\begin{array}{l}\text { Smart mobile } \\
\text { learning } \\
\text { environment with } \\
\text { embodied } \\
\text { intelligent } \\
\text { components }\end{array}$ & $\begin{array}{l}\text { Mobile } \\
\text { application }\end{array}$ & $\begin{array}{l}\text { Learners-centric } \\
\text { and adaptability }\end{array}$ & $\begin{array}{l}\text { Learning styles, user's } \\
\text { profile, user's interest, } \\
\text { socio-emotional traits, } \\
\text { and environmental } \\
\text { context data }\end{array}$ & Context-aware processing layer \\
\hline [81] & $\begin{array}{l}\text { Oyelere et al. } \\
(2018)\end{array}$ & MobileEdu & $\begin{array}{l}\text { Mobile } \\
\text { application }\end{array}$ & $\begin{array}{l}\text { Mobile-based } \\
\text { learning }\end{array}$ & $\begin{array}{l}\text { Micro-lecture materials } \\
\text { and the use of devices } \\
\text { features, such as mobile } \\
\text { data, Bluetooth, Wi-Fi, } \\
\text { and GPS. }\end{array}$ & $\begin{array}{l}\text { Development of a } \\
\text { mobile-learning-supported } \\
\text { course in the computing } \\
\text { curriculum }\end{array}$ \\
\hline [63] & $\begin{array}{l}\text { Arima et al. } \\
(2019)\end{array}$ & Video blog & MOOC & E-Learning & $\begin{array}{l}\text { Educators' background } \\
\text { and experience; } \\
\text { educators' feedback; } \\
\text { educators' discussion; }\end{array}$ & $\begin{array}{l}\text { Advancement of the social } \\
\text { presence of educators }\end{array}$ \\
\hline [61] & Yu et al. (2017) & $\begin{array}{l}\text { Goal Net and } \\
\text { Multi-Agent } \\
\text { Development } \\
\text { Environment } \\
\text { (MADE) }\end{array}$ & MOOC & E-Learning & $\begin{array}{l}\text { Human traits (e.g., } \\
\text { curiosity, emotions) and } \\
\text { video lectures (learning } \\
\text { activities) }\end{array}$ & Personalizing learning Support \\
\hline [73] & $\begin{array}{l}\text { Kelly et al. } \\
(2007)\end{array}$ & Immune Attack & Serious game & $\begin{array}{l}\text { Game-based } \\
\text { learning }\end{array}$ & $\begin{array}{l}\text { Video, 3D model, } \\
\text { information through } \\
\text { clear visual and auditory } \\
\text { media }\end{array}$ & $\begin{array}{l}\text { Integration of learning } \\
\text { biological contents with } \\
\text { gameplay }\end{array}$ \\
\hline [72] & $\begin{array}{l}\text { Oyelere et al. } \\
(2017)\end{array}$ & $\begin{array}{l}\text { Parson's } \\
\text { programming } \\
\text { puzzle }\end{array}$ & Serious game & $\begin{array}{l}\text { Game-based } \\
\text { learning and } \\
\text { mobile-based } \\
\text { learning }\end{array}$ & $\begin{array}{l}\text { Game sessions, } \\
\text { Bluetooth connectivity, } \\
\text { program code, deductive } \\
\text { logic }\end{array}$ & $\begin{array}{l}\text { Integration of board games into } \\
\text { computing education }\end{array}$ \\
\hline [71] & $\begin{array}{l}\text { Yadav and } \\
\text { Oyelere (2021) }\end{array}$ & BaghLearn & Serious game & $\begin{array}{l}\text { Game-based } \\
\text { learning and } \\
\text { mobile-based } \\
\text { learning }\end{array}$ & $\begin{array}{l}\text { Survey of experiences } \\
\text { and interactivity from } \\
\text { the environment }\end{array}$ & $\begin{array}{l}\text { Engaging learners with four } \\
\text { traits of modern learning: } \\
\text { portability, social interaction, } \\
\text { connectivity, individuality }\end{array}$ \\
\hline [75] & $\begin{array}{l}\text { Jovanovic et al. } \\
(2008)\end{array}$ & $\begin{array}{l}\text { V-Strat serious } \\
\text { game }\end{array}$ & Serious game & $\begin{array}{l}\text { Game-based } \\
\text { learning, } \\
\text { discovery-based } \\
\text { learning }\end{array}$ & $\begin{array}{l}\text { Human modality effects } \\
\text { (sensory, perceptual, } \\
\text { motor, cognitive) }\end{array}$ & $\begin{array}{l}\text { Incorporation of motivation } \\
\text { theory principles as well as } \\
\text { multimodal human-computer } \\
\text { interaction. }\end{array}$ \\
\hline [67] & $\begin{array}{l}\text { Lepe-Salazar } \\
(2015)\end{array}$ & GAGE & Serious game & $\begin{array}{l}\text { Model-based game } \\
\text { design and analysis }\end{array}$ & $\begin{array}{l}\text { Survey data and game } \\
\text { performance }\end{array}$ & $\begin{array}{l}\text { Assisting in developing and } \\
\text { analyzing different educational } \\
\text { games }\end{array}$ \\
\hline
\end{tabular}

\section{Discussion}

In this work, we explored the potential of PE and provided an overview of the current scenery to support educational researchers and scholars understand the key considerations 
that govern this novel field. In addition, we discussed how digital learning environments can be transformed into personalized tutoring systems. In the following sub-sections, we align and contextualize the aggregated information in view of the arguments put forward (RQs).

\subsection{From Education to Precision Education}

The essence of 'precision' conveys the necessity of collecting complex and multidimensional data in a systematic and longitudinal way. This is why PE has not received increased attention, especially when compared to other precision-based fields, such as medicine or agriculture. While reviewing the available applications and tools, a set of features that have been provenly supported the conduct of personalized learning interventions, in diverse educational contexts and fields, was identified. Research has shown that initiatives targeted at providing additional support to individuals' needs have significantly impacted student achievement and advancement $[48,108]$. In addition, the conclusions emerged from studies $[51,57]$ describing the research and development efforts to aid students' computational and innovation skills development are also in line with the recommendations provided by the 'Partnership for 21st Century Learning' [109], which feature critical reasoning and creativity amongst the most prevalent skills that students need to develop. Therein, developing tools and methods that can personalize learning not only increases individuals' academic competencies but can also shape their future careers. The true reflection of such education transformation is essential to moving forward, for example, the technology of e-book-based learning system empowering mobile based precision learning though e-annotation, contextualized bookmarking, content searching, and learning process tracking.

\subsection{Integration of Innovative Technologies in Precision Education}

Studies that explore matters related to teaching efficacy [110], student academic efficacy [111], and self-efficacy [112] in conjunction with PE emphasize on the importance of introducing novel AI techniques and methods so that a more personalized or, as commonly determined, 'intelligent' approach can be offered to support learners' needs. By identifying and interpreting individuals' cognitive abilities and behavioral patterns, more tailored and immediate support can be provided to learners without direct input from the instructor [113]. Similarly, influencing students' choice of activities and effort expenditure through immediate support and guidance increases learners' confidence and self-esteem [2]. Like any other industry, the education sector cannot remain static. The $\mathrm{x}$-factor toward this transformation is the integration of new, innovative tools and techniques to facilitate the learning process and improve the learning experience [114]. In this study, we presented and discussed the key features of dynamic technologies that contribute to this evolution. For instance, the $i$ Write tool [107] enables students to manage their individual tasks and assignments in collaborative learning activities, whereas the GAGE tool [67] helps young and novice developers to build educational games by providing them with insights and hints emerging from pre-existing games.

\subsection{Multimodal Data and Precision Education}

The adoption of multimodal tools to collect data related to learners' characteristics, behavior, interactions, and performance enables instructors to better understand students needs [55]. In addition, it allows for the integration of inclusive and reflective tasks tailored to individuals' particular needs and competencies [57]. Such outcomes align with the information gathered concerning the features that the presented digital (learning) solutions offer to support the conduct of PE practices. It can, therefore, be inferred that to provide learners with a more personalized learning experience, instructors and educational technologists need not only to focus on the pedagogical elements of the delivered interventions but also on the ways that learners react to the given stimuli. Therefore, exploring matters related to the interplay between the teachers and the students from multiple perspectives and points of view becomes a strong necessity. In the context of this process, researchers 
and instructional designers should examine carefully the interconnectivity between the traditional pedagogical approaches and the features of the environments in which they are taking place. To this end, depending on a single learning environment might not be inclusive enough for students to develop their skills. Hence, introducing multiple learning sources not only facilitates individuals' learning needs but also allows for the collection of multimodal data without spatiotemporal constraints.

\section{Conclusions and Future Directions}

The findings and directions emerging from the reviewed studies offer valuable information and enlightening insights which can support practitioners' decision making and future actions. However, the potential of PE to enhance the learning experience and, therefore, outcomes can only be achieved if the respective attempts and efforts are made in a systematic and longitudinal way. To achieve this goal, any prospect efforts to tailor (personalize) the instructional process should be done through applied research, performed in the context where teaching-and-learning activities primarily take place (i.e., schools, universities), as part of students' routine practice. Moreover, such integrations should be evaluated via multidimensional feasibility and empirical studies using modified tools, adaptive learning materials, and assessment methods. Collectively, it can be argued that, together with the evolution of emerging technologies, more sophisticated digital learning tools, precision-based instructional approaches and evaluation measurements will become available. On these grounds, we speculate that PE presents a promising yet challenging avenue to pursue.

To this end, it is essential to first identify and determine the various challenges and shortcomings that the current practices present. The selected examples and directions mentioned above pave the pathway for research and development both on the theoretical level and on practical grounds. Therefore, future researchers are advised to focus on the development of protocols that can support the provision of personalized instruction and further explore approaches that can be utilized to integrate corrective measures when needed. Likewise, heuristic data collection instruments can be designed with PE in mind so that new frameworks and models can be developed to complement the data collected via multimodal tools. Finally, researchers focusing on this direction should also consider the recommendation made by Hart [8] concerning the duration of such efforts (i.e., long-term) as information acquired from near-term experiments may hinder the potential of PE.

\section{Implications for Practice and Policy}

The growing interest of educational researchers in identifying the underneath benefits and opportunities of PE signals the start of a new era that requires scholars and policymakers to lay out practices and policies for long-term sustainability with reciprocal emphasis and assurance on precision teaching and learning. The recommendations provided below can be considered guidelines, not only for those researchers who perform studies related to PE but also for practitioners (e.g., educators, instructional designers) who utilize smart learning environments or other forms of TEL applications with multimodality features.

- The acquisition of skills (e.g., problem-solving, critical thinking, reasoning, creativity, fluency) that STEM (science, technology, engineering, mathematics) education students need to develop is challenging and demanding regardless of the technological aids being used. Therefore, identifying learners' characteristics and behavioral traits will enable educational stakeholders (e.g., technologists, educators) to provide personalized and adaptive instructional paradigms aligned to the competencies and needs of their learners.

- The discussed educational technologies have been established and evolved in the ongoing research and development efforts that aim to provide tailored tutoring opportunities to learners with diverse needs and cultural backgrounds. Therein, by integrating multimodal tools which, for instance, can gather information related to learners' visual engagement or kinesthetic reactions to diverse stimuli, can comple- 
ment the development of the so-called 'learner profile' and thus provide insights related to the development of a better understanding toward the learning strategies, preferences, and styles that individuals have.

- Another possible impediment to sustainable PE is the lack of combination and validity in conceptualization and contextualization in deciding the required resources, processes, and structures. Regardless of the principles on which a learning environment is developed, PE necessitates early multivariate evaluations to use multimodal technologies.

- Given the infancy stage of PE, policymakers and regulators are also advised to support and facilitate the conduct of multidisciplinary research so that all the relevant aspects (e.g., ethics, security, cultural and societal norms) be covered both adequately and succinctly.

Author Contributions: Conceptualization: U.B.Q., S.S.O., and A.C.; writing—original draft: U.B.Q.; writing—-review and editing: U.B.Q., A.C., and S.S.O.; validation: U.B.Q., A.C., S.S.O., M.-J.L., and H.O.; resources: H.O., M.-J.L. All authors have read and agreed to the published version of the manuscript.

Funding: This research received no external funding.

Institutional Review Board Statement: Not applicable.

Informed Consent Statement: Not applicable.

Data Availability Statement: Not applicable.

Conflicts of Interest: The authors declare no conflict of interest.

\section{Appendix A}

Table A1. Summary of selected multidisciplinary studies that support integration of multimodality in Precision Education.

\begin{tabular}{|c|c|c|c|c|c|c|}
\hline No & Reference & Tools & Area & Pedagogy & $\begin{array}{l}\text { Multimodality } \\
\text { Features }\end{array}$ & $\begin{array}{l}\text { Precision } \\
\text { Education } \\
\text { (Context) }\end{array}$ \\
\hline [49] & Siegler et al. (2012) & $\begin{array}{l}\text { British Cohort Study (BCS), } \\
\text { Panel Study of Income } \\
\text { Dynamics-Child Development } \\
\text { Supplement (PSIDCDS) }\end{array}$ & Multidisciplinary & $\begin{array}{l}\text { Analytics-based } \\
\text { assessment }\end{array}$ & $\begin{array}{c}\text { Mathematical } \\
\text { literature data, } \\
\text { demographic data }\end{array}$ & $\begin{array}{c}\text { Mathematical skills } \\
\text { development }\end{array}$ \\
\hline [95] & Ho et al. (2009) & $\begin{array}{l}\text { Particle swarm optimization } \\
\text { (PSO) algorithm }\end{array}$ & Multidisciplinary & $\begin{array}{l}\text { Computer } \\
\text { supported } \\
\text { collaborative } \\
\text { learning }\end{array}$ & $\begin{array}{c}\text { Student } \\
\text { characteristics such } \\
\text { as learning style or } \\
\text { concern with } \\
\text { interactions }\end{array}$ & $\begin{array}{l}\text { Increasing social } \\
\text { interactions among } \\
\text { learners without the } \\
\text { constraint of time } \\
\text { and space }\end{array}$ \\
\hline [12] & $\begin{array}{l}\text { Gulson and Webb } \\
\text { (2018) }\end{array}$ & $\begin{array}{l}\text { Life intervention, optimization } \\
\text { and computation method }\end{array}$ & Multidisciplinary & $\begin{array}{l}\text { Discovery-based } \\
\text { learning and } \\
\text { discourse-based } \\
\text { policy development }\end{array}$ & $\begin{array}{l}\text { Cognitive, physical } \\
\text { human attributes, } \\
\text { and biometric data }\end{array}$ & $\begin{array}{l}\text { Transformation of } \\
\text { thinking, knowing, } \\
\text { living life }\end{array}$ \\
\hline [46] & $\begin{array}{l}\text { Temple and Doerr } \\
\text { (2012). }\end{array}$ & $\begin{array}{l}\text { Mathematical register and } \\
\text { Discourse Analysis }\end{array}$ & Multidisciplinary & $\begin{array}{l}\text { Method-based } \\
\text { interventions }\end{array}$ & $\begin{array}{l}\text { Audiotapes, } \\
\text { transcripts, lessons } \\
\text { videos }\end{array}$ & $\begin{array}{l}\text { Identification of } \\
\text { interactional } \\
\text { strategies }\end{array}$ \\
\hline [52] & Vostanis et al. (2020) & $\begin{array}{c}\text { Frequency building to a } \\
\text { performance criterion (FBPC), } \\
\text { component-composite analysis }\end{array}$ & Multidisciplinary & $\begin{array}{l}\text { Method-based } \\
\text { interventions }\end{array}$ & $\begin{array}{l}\text { Behavioral } \\
\text { measures: level, } \\
\text { level change } \\
\text { multiplier, } \\
\text { celebration, bounce, } \\
\text { frequency } \\
\text { multiplier. }\end{array}$ & $\begin{array}{c}\text { Mathematics ability } \\
\text { development with } \\
\text { intellectual or } \\
\text { developmental } \\
\text { disability (IDD) }\end{array}$ \\
\hline [28] & Boticki et al. (2019) & Learning Log Processing Model & Multidisciplinary & $\begin{array}{l}\text { Model-based } \\
\text { learning analysis }\end{array}$ & $\begin{array}{l}\text { Non-structured } \\
\text { learning log data } \\
\text { (sessions, reads, } \\
\text { read passages, and } \\
\text { read passage pairs) }\end{array}$ & $\begin{array}{l}\text { Identification of } \\
\text { e-book reading } \\
\text { styles }\end{array}$ \\
\hline [62] & $\begin{array}{l}\text { Chang and Smith } \\
\text { (2008) }\end{array}$ & $\begin{array}{c}\text { Students' Perceived Interaction } \\
\text { Survey (SPIS) }\end{array}$ & Multidisciplinary & $\begin{array}{l}\text { Satisfaction and } \\
\text { learner-centered } \\
\text { distance education }\end{array}$ & $\begin{array}{c}\text { Student perceptions, } \\
\text { course } \\
\text { satisfaction, } \\
\text { experiences, and } \\
\text { demographics }\end{array}$ & $\begin{array}{l}\text { Identification of } \\
\text { student's } \\
\text { satisfaction in } \\
\text { different stages of } \\
\text { distance education }\end{array}$ \\
\hline
\end{tabular}


Table A1. Cont.

\begin{tabular}{|c|c|c|c|c|c|c|}
\hline No & Reference & Tools & Area & Pedagogy & $\begin{array}{l}\text { Multimodality } \\
\text { Features }\end{array}$ & $\begin{array}{l}\text { Precision } \\
\text { Education } \\
\text { (Context) }\end{array}$ \\
\hline [40] & Cook et al. (2018) & $\begin{array}{c}\text { Science of Precision care } \\
\text { services }\end{array}$ & Multidisciplinary & $\begin{array}{l}\text { Service-based } \\
\text { interventions }\end{array}$ & $\begin{array}{c}\text { Academic, } \\
\text { behavioral, } \\
\text { emotional, Physical } \\
\text { health difficulties, }\end{array}$ & $\begin{array}{c}\text { Data-based decision } \\
\text { making and } \\
\text { intervention }\end{array}$ \\
\hline [55] & $\begin{array}{l}\text { Veerasamy et al. } \\
\text { (2016) }\end{array}$ & Delphi concept inventory & Multidisciplinary & $\begin{array}{l}\text { Technology- } \\
\text { enhanced } \\
\text { program }\end{array}$ & $\begin{array}{l}\text { Misconceptions and } \\
\text { knowledge-based } \\
\text { coding errors }\end{array}$ & $\begin{array}{l}\text { Identifying novice } \\
\text { student } \\
\text { programming } \\
\text { misconceptions and } \\
\text { errors }\end{array}$ \\
\hline [36] & $\begin{array}{l}\text { Paredes } \\
\text { Barragán and } \\
\text { Rodríguez } \\
\text { Marín (2002) }\end{array}$ & $\begin{array}{l}\text { FELDER-SILVERMAN } \\
\text { Learning style Model }\end{array}$ & Multidisciplinary & $\begin{array}{l}\text { Web-based } \\
\text { education }\end{array}$ & $\begin{array}{l}\text { Student behavior: } \\
\text { learning styles }\end{array}$ & $\begin{array}{l}\text { Improvement of the } \\
\text { efficiency and } \\
\text { adaptability to } \\
\text { individual learning } \\
\text { characteristics }\end{array}$ \\
\hline
\end{tabular}

\section{References}

1. Popenici, S.A.D.; Kerr, S. Exploring the Impact of Artificial Intelligence on Teaching and Learning in Higher Education. Res. Pract. Technol. Enhanc. Learn. 2017, 12, 22. [CrossRef]

2. Christopoulos, A.; Kajasilta, H.; Salakoski, T.; Laakso, M.-J. Limits and Virtues of Educational Technology in Elementary School Mathematics. J. Educ. Technol. Syst. 2020, 49, 59-81. [CrossRef]

3. Pratt, K.; Kovatcheva, E.P. Designing Blended, Flexible, and Personalized Learning. In Second Handbook of Information Technology in Primary and Secondary Education; Voogt, J., Knezek, G., Christensen, R., Lai, K.-W., Eds.; Springer International Handbooks of Education; Springer International Publishing: Cham, Switzerland, 2018; pp. 759-776.

4. Fok, A.W.P.; Ip, H.H.S. Personalized Education: An Exploratory Study of Learning Pedagogies in Relation to Personalization Technologies. In Advances in Web-Based Learning-ICWL 2004; Liu, W., Shi, Y., Li, Q., Eds.; Lecture Notes in Computer Science; Springer: Berlin, Germany, 2004; pp. 407-415.

5. Chusni, M.M.; Saputro, S.; Rahardjo, S.B. The Conceptual Framework of Designing a Discovery Learning Modification Model to Empower Students' Essential Thinking Skills. J. Phys. Conf. Ser. 2020, 1467, 012015. [CrossRef]

6. Martinez-Maldonado, R.; Elliott, D.; Axisa, C.; Power, T.; Echeverria, V.; Shum, S.B. Designing Translucent Learning Analytics with Teachers: An Elicitation Process. Interact. Learn. Environ. 2020, 1-15. [CrossRef]

7. Tsai, S.-C.; Chen, C.-H.; Shiao, Y.-T.; Ciou, J.-S.; Wu, T.-N. Precision Education with Statistical Learning and Deep Learning: A Case Study in Taiwan. Int. J. Educ. Technol. High Educ. 2020, 17, 12. [CrossRef]

8. Hart, S.A. Precision Education Initiative: Moving Toward Personalized Education. Mind Brain Educ. 2016, 10, 209-211. [CrossRef] [PubMed]

9. Williamson, B. Personalized Precision Education and Intimate Data Analytics, 2018. Code Acts Educ. Available online: https: / / codeactsineducation.wordpress.com/2018/04/16/personalized-precision-education/ (accessed on 5 July 2021).

10. Kuch, D.; Kearnes, M.; Gulson, K. The Promise of Precision: Datafication in Medicine, Agriculture and Education. Policy Stud. 2020, 41, 527-546. [CrossRef]

11. Williamson, B. Big Data in Education: The Digital Future of Learning, Policy and Practice; SAGE: London, UK, 2017.

12. Gulson, K.N.; Webb, P.T. 'Life' and Education Policy: Intervention, Augmentation and Computation. Discourse Stud. Cult. Politics Educ. 2018, 39, 276-291. [CrossRef]

13. Williamson, B. Digital Policy Sociology: Software and Science in Data-Intensive Precision Education. Crit. Stud. Educ. 2019, 1-17. [CrossRef]

14. Pykett, J.; Disney, T. Brain-Targeted Teaching and the Biopolitical Child. In Politics, Citizenship and Rights; Kallio, K.P., Mills, S., Skelton, T., Eds.; Geographies of Children and Young People; Springer: Singapore, 2016; pp. 133-152.

15. Reber, R.; Canning, E.A.; Harackiewicz, J.M. Personalized Education to Increase Interest. Curr. Dir. Psychol. Sci. 2018, 27, 449-454. [CrossRef]

16. Gao, P. Using Personalized Education to Take the Place of Standardized Education. J. Educ. Train. Stud. 2014, 2, 44-47. [CrossRef]

17. Burns, M.K.; Davidson, K.; Zaslofsky, A.F.; Parker, D.C.; Maki, K.E. The Relationship between Acquisition Rate for Words and Working Memory, Short-Term Memory, and Reading Skills: Aptitude-by-Treatment or Skill-by-Treatment Interaction? Assess. Eff. Interv. 2018, 43, 182-192. [CrossRef]

18. Wilhelm, S.; Phillips, K.A.; Didie, E.; Buhlmann, U.; Greenberg, J.L.; Fama, J.M.; Keshaviah, A.; Steketee, G. Modular CognitiveBehavioral Therapy for Body Dysmorphic Disorder: A Randomized Controlled Trial. Behav. Ther. 2014, 45, 314-327. [CrossRef]

19. Tempelaar, D.; Rienties, B.; Nguyen, Q. The Contribution of Dispositional Learning Analytics to Precision Education. Educ. Technol. Soc. 2021, 24, 109-122.

20. Luan, H.; Tsai, C.-C. A Review of Using Machine Learning Approaches for Precision Education. Educ. Technol. Soc. 2021, 24, $250-266$.

21. Chen, X.; Zou, D.; Xie, H.; Cheng, G. Twenty Years of Personalized Language Learning. Educ. Technol. Soc. 2021, 24, 205-222. 
22. Zhang, L.; Basham, J.D.; Yang, S. Understanding the Implementation of Personalized Learning: A Research Synthesis. Educ. Res. Rev. 2020, 31, 100339. [CrossRef]

23. Wartman, S.A.; Combs, C.D. Medical Education Must Move from the Information Age to the Age of Artificial Intelligence. Acad. Med. 2018, 93, 1107-1109. [CrossRef]

24. Lindsley, O.R. Precision Teaching in Perspective: An Interview with Ogden R. Lindsley. Teach. Except. Child. $1971,3,114-119$.

25. White, O.R. Precision Teaching-Precision Learning. Except. Child. 1986, 52, 522-534. [CrossRef]

26. McDade, C.E. Computer-Based Precision Learning: A Course Builder Application. Behav. Res. Methods Instrum. Comput. 1992, 24, 269-272. [CrossRef]

27. Yang, S.J.H. Precision Education: New Challenges for AI in Education [Conference Keynote]. In Proceedings of the 27th International Conference on Computers in Education (ICCE). Taiwan: Asia-Pacific Society for Computers in Education, Kenting, Taiwan, 2-6 December 2019; pp. 27-28.

28. Boticki, I.; Ogata, H.; Tomiek, K.; Akçapınar, G.; Flanagan, B.; Majumdar, R.; Hasnine, M. Identifying Reading Styles from E-Book Log Data. In Proceedings of the 27th International Conference on Computers in Education (ICCE), Kenting, Taiwan, 2-6 December 2019.

29. Ogata, H.; Oi, M.; Mohri, K.; Okubo, F.; Shimada, A.; Yamada, M.; Wang, J.; Hirokawa, S. Learning Analytics for E-Book-Based Educational Big Data in Higher Education. In Smart Sensors at the IoT Frontier; Yasuura, H., Kyung, C.-M., Liu, Y., Lin, Y.-L., Eds.; Springer International Publishing: Cham, Switzerland, 2017; pp. 327-350.

30. Meglio, O.; Risberg, A. The (Mis) Measurement of M\&A Performance-A Systematic Narrative Literature Review. Scand. J. Manag. 2011, 27, 418-433.

31. Baumeister, R.F.; Leary, M.R. Writing Narrative Literature Reviews. Rev. Gen. Psychol. 1997, 1, 311-320. [CrossRef]

32. Siddaway, A.P.; Wood, A.M.; Hedges, L.V. How to Do a Systematic Review: A Best Practice Guide for Conducting and Reporting Narrative Reviews, Meta-Analyses, and Meta-Syntheses. Annu. Rev. Psychol. 2019, 70, 747-770. [CrossRef]

33. Dixon-Woods, M.; Agarwal, S.; Jones, D.; Young, B.; Sutton, A. Synthesising Qualitative and Quantitative Evidence: A Review of Possible Methods. J. Health Serv. Res. Policy 2005, 10, 45-53. [CrossRef] [PubMed]

34. Henry, B.M.; Skinningsrud, B.; Vikse, J.; Pękala, P.A.; Walocha, J.A.; Loukas, M.; Tubbs, R.S.; Tomaszewski, K.A. Systematic Reviews versus Narrative Reviews in Clinical Anatomy: Methodological Approaches in the Era of Evidence-based Anatomy. Clin. Anat. 2018, 31, 364-367. [CrossRef] [PubMed]

35. Sharma, K.; Giannakos, M. Multimodal Data Capabilities for Learning: What Can Multimodal Data Tell Us about Learning? Br. J. Educ. Technol. 2020, 51, 1450-1484. [CrossRef]

36. Barragán, P.P.; Marín, P.R. Considering Learning Styles in Adaptative Web-Based Education; International Institute of Informatics and Systemics: Winter Garden, FL, USA, 2002.

37. Qushem, U.B.; Zeki, A.M.; Abubakar, A. Successful Business Intelligence System for SME: An Analytical Study in Malaysia. In IOP Conference Series: Materials Science and Engineering; IOP Publishing: Bristol, UK, 2017; Volume 226, p. 012090.

38. García, P.; Amandi, A.; Schiaffino, S.; Campo, M. Evaluating Bayesian Networks' Precision for Detecting Students' Learning Styles. Comput. Educ. 2007, 49, 794-808. [CrossRef]

39. Commons, M.L.; Owens, C.J.; Will, S.M. Using a Computer-Based Precision Teaching Program to Facilitate Learning of Complex Material: The Case of the Model of Hierarchical Complexity. Behav. Dev. Bull. 2015, 20, 207. [CrossRef]

40. Cook, C.R.; Kilgus, S.P.; Burns, M.K. Advancing the Science and Practice of Precision Education to Enhance Student Outcomes. J. Sch. Psychol. 2018, 66, 4-10. [CrossRef]

41. Bloom, B.S. Automaticity: The Hands and Feet of Genius. Educ. Leadersh. 1986, 43, 70-77.

42. Lindsley, O.R. Why Aren't Effective Teaching Tools Widely Adopted? J Appl. Behav. Anal. 1992, 25, 21-26. [CrossRef]

43. Binder, C. Doesn't Everybody Need Fluency? Perform. Improv. 2003, 42, 14-20. [CrossRef]

44. Geary, D.C.; Brown, S.C. Cognitive Addition: Strategy Choice and Speed-of-Processing Differences in Gifted, Normal, and Mathematically Disabled Children. Dev. Psychol. 1991, 27, 398. [CrossRef]

45. Jordan, N.C.; Montani, T.O. Cognitive Arithmetic and Problem Solving: A Comparison of Children with Specific and General Mathematics Difficulties. J. Learn. Disabil. 1997, 30, 624-634. [CrossRef] [PubMed]

46. Temple, C.; Doerr, H.M. Developing Fluency in the Mathematical Register through Conversation in a Tenth-Grade Classroom. Educ. Stud. Math. 2012, 81, 287-306. [CrossRef]

47. Beck, R.; Clement, R. The Great Falls Precision Teaching Project: An Historical Examination. J. Precis. Teach. 1991, 8, 8-12.

48. Germeroth, C.; Kelleman, B.; Spartz, J. Lyrics2Learn: Teaching Fluency through Music and Technology. Educ. Sci. 2018, 8, 91. [CrossRef]

49. Siegler, R.S.; Duncan, G.J.; Davis-Kean, P.E.; Duckworth, K.; Claessens, A.; Engel, M.; Susperreguy, M.I.; Chen, M. Early Predictors of High School Mathematics Achievement. Psychol. Sci. 2012, 23, 691-697. [CrossRef]

50. Geary, D.C.; Hoard, M.K.; Nugent, L.; Bailey, D.H. Adolescents' Functional Numeracy Is Predicted by Their School Entry Number System Knowledge. PLoS ONE 2013, 8, e54651. [CrossRef]

51. Connor, C.M.; Mazzocco, M.M.M.; Kurz, T.; Crowe, E.C.; Tighe, E.L.; Wood, T.S.; Morrison, F.J. Using Assessment to Individualize Early Mathematics Instruction. J. Sch. Psychol. 2018, 66, 97-113. [CrossRef]

52. Vostanis, A.; Padden, C.; Chiesa, M.; Rizos, K.; Langdon, P.E. A Precision Teaching Framework for Improving Mathematical Skills of Students with Intellectual and Developmental Disabilities. J. Behav. Educ. 2020, 1-21. [CrossRef] 
53. Blömeke, S.; Suhl, U.; Kaiser, G. Teacher Education Effectiveness: Quality and Equity of Future Primary Teachers' Mathematics and Mathematics Pedagogical Content Knowledge. J. Teach. Educ. 2011, 62, 154-171. [CrossRef]

54. Durak, H.Y. The Effects of Using Different Tools in Programming Teaching of Secondary School Students on Engagement, Computational Thinking and Reflective Thinking Skills for Problem Solving. Technol. Knowl. Learn. 2020, 25, 179-195. [CrossRef]

55. Veerasamy, A.K.; D’Souza, D.; Laakso, M.-J. Identifying Novice Student Programming Misconceptions and Errors From Summative Assessments. J. Educ. Technol. Syst. 2016, 45, 50-73. [CrossRef]

56. Fessakis, G.; Gouli, E.; Mavroudi, E. Problem Solving by 5-6 Years Old Kindergarten Children in a Computer Programming Environment: A Case Study. Comput. Educ. 2013, 63, 87-97. [CrossRef]

57. Laakso, M.-J.; Kaila, E.; Rajala, T. ViLLE_Collaborative Education Tool: Designing and Utilizing an Exercise-Based Learning Environment. Educ. Inf. Technol. 2018, 23, 1655-1676. [CrossRef]

58. Baer, L.; Campbell, J. From Metrics to Analytics, Reporting to Action: Analytics' Role in Changing the Learning Environment. In Game Changers: Education and Information Technologies; Educause: Boulder, CO, USA, 2012; pp. 53-65.

59. Savi, A.O.; Maas, H.L.J.; van der Maris, G.K.J. Navigating Massive Open Online Courses. Science 2015, 347, 958. [CrossRef] [PubMed]

60. Childre, A.; Sands, J.R.; Pope, S.T. Backward Design: Targeting Depth of Understanding for All Learners. Teach. Except. Child. 2009, 41, 6-14. [CrossRef]

61. Yu, H.; Miao, C.; Leung, C.; White, T.J. Towards AI-Powered Personalization in MOOC Learning. NPJ Sci. Learn. 2017, 2, 1-5. [CrossRef]

62. Chang, S.-H.H.; Smith, R.A. Effectiveness of Personal Interaction in a Learner-Centered Paradigm Distance Education Class Based on Student Satisfaction. J. Res. Technol. Educ. 2008, 40, 407-426. [CrossRef]

63. Arima, S.; Miyakita, G.; Yasui, M.; Okawa, K. Enhancing Educators' Social Presence in MOOCs: Design of Daily Video Blog. In Proceedings of the 2019 IEEE Learning with MOOCS (LWMOOCS), Milwaukee, WI, USA, 23-25 October 2019 ; pp. 36-41.

64. Kulkarni, C.; Wei, K.P.; Le, H.; Chia, D.; Papadopoulos, K.; Cheng, J.; Koller, D.; Klemmer, S.R. Peer and Self Assessment in Massive Online Classes. ACM Trans. Comput. Hum. Interact. 2013, 20, 33:1-33:31. [CrossRef]

65. Stevens, D.D.; Levi, A.J. Introduction to Rubrics: An Assessment Tool to Save Grading Time, Convey Effective Feedback, and Promote Student Learning; Stylus Publishing, LLC: Sterling, VA, USA, 2013.

66. Skinner, E.A.; Belmont, M.J. Motivation in the Classroom: Reciprocal Effects of Teacher Behavior and Student Engagement across the School Year. J. Educ. Psychol. 1993, 85, 571-581. [CrossRef]

67. Lepe-Salazar, F. A Model to Analyze and Design Educational Games with Pedagogical Foundations. In Proceedings of the 12th International Conference on Advances in Computer Entertainment Technology, New York, NY, USA, 16-19 November 2015; pp. 1-14. [CrossRef]

68. Dondlinger, M. Educational Video Game Design: A Review of the Literature. J. Appl. Educ. Technol. 2007, 4, 21-31.

69. Gee, J.P. What Video Games Have to Teach Us about Learning and Literacy. Comput. Entertain. 2003, 1, 20. [CrossRef]

70. Mayo, M.J. Games for Science and Engineering Education. Commun. ACM 2007, 50, 30-35. [CrossRef]

71. Yadav, A.K.; Oyelere, S.S. Contextualized Mobile Game-Based Learning Application for Computing Education. Educ. Inf. Technol. 2021, 26, 2539-2562. [CrossRef]

72. Oyelere, S.S.; Suhonen, J.; Laine, T.H. Integrating Parson's Programming Puzzles into a Game-Based Mobile Learning Application. In Proceedings of the 17th Koli Calling International Conference on Computing Education Research, New York, NY, USA, 16-19 November 2017; pp. 158-162.

73. Kelly, H.; Howell, K.; Glinert, E.; Holding, L.; Swain, C.; Burrowbridge, A.; Roper, M. How to Build Serious Games. Commun. ACM 2007, 50, 44-49. [CrossRef]

74. Carr, D. Contexts, Gaming Pleasures, and Gendered Preferences. Simul. Gaming 2005, 36, 464-482. [CrossRef]

75. Jovanovic, M.; Starcevic, D.; Stavljanin, V.; Minovic, M. Surviving the Design of Educational Games: Borrowing from Motivation and Multimodal Interaction. In Proceedings of the 2008 Conference on Human System Interactions, Krakow, Poland, 25-27 May 2008; pp. 194-198.

76. Bouali, N.; Nygren, E.; Oyelere, S.S.; Suhonen, J.; Cavalli-Sforza, V. Imikode: A VR Game to Introduce OOP Concepts. In Proceedings of the 19th Koli Calling International Conference on Computing Education Research, New York, NY, USA, 21-24 November 2019; pp. 1-2.

77. Eck, R.V. Building Artificially Intelligent Learning Games. Available online: www.igi-global.com/chapter/games-simulationsonline-learning/18780 (accessed on 29 May 2021).

78. Agbo, F.J.; Oyelere, S.S.; Suhonen, J.; Laine, T.H. Co-Design of Mini Games for Learning Computational Thinking in an Online Environment. Educ. Inf. Technol. 2021, 1-35. [CrossRef]

79. Streicher, A.; Smeddinck, J.D. Personalized and Adaptive Serious Games. In Entertainment Computing and Serious Games: International GI-Dagstuhl Seminar 15283, Dagstuhl Castle, Germany, 5-10 July 2015; Dörner, R., Göbel, S., Kickmeier-Rust, M., Masuch, M., Zweig, K., Eds.; Lecture Notes in Computer Science; Springer International Publishing: Cham, Switzerland, 2016; pp. 332-377. [CrossRef]

80. Peirce, N.; Conlan, O.; Wade, V. Adaptive Educational Games: Providing Non-Invasive Personalised Learning Experiences. In Proceedings of the 2008 Second IEEE International Conference on Digital Game and Intelligent Toy Enhanced Learning, Banff, AB, Canada, 17-19 November 2008; pp. 28-35. 
81. Oyelere, S.S.; Suhonen, J.; Wajiga, G.M.; Sutinen, E. Design, Development, and Evaluation of a Mobile Learning Application for Computing Education. Educ. Inf. Technol. 2018, 23, 467-495. [CrossRef]

82. Qushem, U.B.; Dahlan, A.R.B.A.; Ghani, A.S.B.M. My Emergency Assistant Device: A Conceptual Solution in Enhancing the Quality of Life for the Disabled and Elderly. In Proceedings of the 2016 6th International Conference on Information and Communication Technology for The Muslim World (ICT4M), Jakarta, Indonesia, 22-24 November 2016; pp. 82-87.

83. Agbo, F.J.; Oyelere, S.S. Smart Mobile Learning Environment for Programming Education in Nigeria: Adaptivity and ContextAware Features. In Intelligent Computing; Arai, K., Bhatia, R., Kapoor, S., Eds.; Advances in Intelligent Systems and Computing; Springer International Publishing: Cham, Switzerland, 2019; pp. 1061-1077.

84. Chen, C.-H.; Su, C.-Y. Using the BookRoll E-Book System to Promote Self-Regulated Learning, Self-Efficacy and Academic Achievement for University Students. J. Educ. Technol. Soc. 2019, 22, 33-46.

85. Mouri, K.; Uosaki, N.; Ogata, H. Learning Analytics for Supporting Seamless Language Learning Using E-Book with Ubiquitous Learning System. J. Educ. Technol. Soc. 2018, 21, 150-163.

86. Huang, Y.-M.; Liang, T.-H.; Su, Y.-N.; Chen, N.-S. Empowering Personalized Learning with an Interactive E-Book Learning System for Elementary School Students. Educ. Technol. Res. Dev. 2012, 60, 703-722. [CrossRef]

87. Hourcade, J.P.; Bederson, B.B.; Druin, A.; Rose, A.; Farber, A.; Takayama, Y. The International Children's Digital Library: Viewing Digital Books Online. Interact. Comput. 2003, 15, 151-167. [CrossRef]

88. de Jong, M.T.; Bus, A.G. How Well Suited Are Electronic Books to Supporting Literacy? J. Early Child. Lit. 2003, 3, 147-164. [CrossRef]

89. Lee, K. Augmented Reality in Education and Training. TechTrends 2012, 56, 13-21. [CrossRef]

90. Christopoulos, A.; Conrad, M.; Shukla, M. Increasing Student Engagement through Virtual Interactions: How? Virtual Real. 2018, 22, 353-369. [CrossRef]

91. Agbo, F.J.; Sanusi, I.T.; Oyelere, S.S.; Suhonen, J. Application of Virtual Reality in Computer Science Education: A Systemic Review Based on Bibliometric and Content Analysis Methods. Educ. Sci. 2021, 11, 142. [CrossRef]

92. Oyelere, S.S.; Bouali, N.; Kaliisa, R.; Obaido, G.; Yunusa, A.A.; Jimoh, E.R. Exploring the Trends of Educational Virtual Reality Games: A Systematic Review of Empirical Studies. Smart Learn. Environ. 2020, 7, 31. [CrossRef]

93. Martín-Gutiérrez, J.; Mora, C.E.; Añorbe-Díaz, B.; González-Marrero, A. Virtual Technologies Trends in Education. EURASIA J. Math. Sci. Technol. Educ. 2017, 13, 469-486. [CrossRef]

94. Kim, J.-H.; Park, S.-T.; Lee, H.; Yuk, K.-C.; Lee, H. Virtual Reality Simulations in Physics Education. Interact. Multimed. Electron. J. Comput. Enhanc. Learn. 2001, 3, 1-7.

95. Ho, T.; Shyu, S.J.; Wang, F.; Li, C.T. Composing High-Heterogeneous and High-Interaction Groups in Collaborative Learning with Particle Swarm Optimization. In Proceedings of the 2009 WRI World Congress on Computer Science and Information Engineering, Washington, DC, USA, 31 March-2 April 2009; Volume 4, pp. 607-611.

96. Pellas, N.; Dengel, A.; Christopoulos, A. A Scoping Review of Immersive Virtual Reality in STEM Education. IEEE Trans. Learn. Technol. 2020, 13, 748-761. [CrossRef]

97. Wang, M.; Callaghan, V.; Bernhardt, J.; White, K.; Peña-Rios, A. Augmented Reality in Education and Training: Pedagogical Approaches and Illustrative Case Studies. J. Ambient. Intell. Humaniz. Comput. 2018, 9, 1391-1402. [CrossRef]

98. Christopoulos, A.; Conrad, M.; Shukla, M. The added value of the hybrid virtual learning approach: Using virtual environments in the real classroom. In Integrating Multi-User Virtual Environments in Modern Classrooms; IGI Global: Hershey PA, USA, 2018; pp. 259-279.

99. Di Serio, Á.; Ibáñez, M.B.; Kloos, C.D. Impact of an Augmented Reality System on Students' Motivation for a Visual Art Course. Comput. Educ. 2013, 68, 586-596. [CrossRef]

100. Christopoulos, A.; Conrad, M.; Shukla, M. Objects, worlds, and students: Virtual interaction in education. Educ. Res. Int. 2014, 2014. [CrossRef]

101. Christopoulos, A.; Conrad, M.; Shukla, M. What Does the Pedagogical Agent Say? In Proceedings of the 10th International Conference on Information, Intelligence, Systems and Applications (IISA), Patras, Greece, 15-19 July 2019; pp. 1-7.

102. Wang, F.; Liu, Y.; Tian, M.; Zhang, Y.; Zhang, S.; Chen, J. Application of a 3D Haptic Virtual Reality Simulation System for Dental Crown Preparation Training. In Proceedings of the 2016 8th International Conference on Information Technology in Medicine and Education (ITME), Fuzhou, China, 23-25 December 2016; pp. 424-427.

103. Fonseca, D.; Martí, N.; Redondo, E.; Navarro, I.; Sánchez, A. Relationship between Student Profile, Tool Use, Participation, and Academic Performance with the Use of Augmented Reality Technology for Visualized Architecture Models. Comput. Hum. Behav. 2014, 31, 434-445. [CrossRef]

104. Freitas, R.; Campos, P. SMART: A System of Augmented Reality for Teaching 2nd Grade Students. People Comput. XXII Cult. Creat. Interact. 2008, 27-30. [CrossRef]

105. Chen, H. Construction and Application of Precise Teaching Mode Based on Cloud Classroom in the Context of Blended Teaching. Front. Educ. Res. 2019, 2, 67-73. [CrossRef]

106. Yuan, Y. Cloud Classroom Boost Online Learning and Educational Resources Sharing. In Proceedings of the 2016 International Symposium on Educational Technology (ISET), Beijing, China, 19-21 July 2016; pp. 80-83.

107. Calvo, R.A.; O’Rourke, S.T.; Jones, J.; Yacef, K.; Reimann, P. Collaborative Writing Support Tools on the Cloud. IEEE Trans. Learn. Technol. 2011, 4, 88-97. [CrossRef] 
108. Kersten, J.; Pardo, L. Finessing and Hybridizing: Innovative Literacy Practices in Reading First Classrooms. Read. Teach. 2007, 61, 146-154. [CrossRef]

109. P21's Framework for 21st Century Learning; Betelle for Kids: Columbus, Ohio, USA, 2019.

110. Hechter, R.P. Changes in Preservice Elementary Teachers' Personal Science Teaching Efficacy and Science Teaching Outcome Expectancies: The Influence of Context. J. Sci. Teach. Educ. 2011, 22, 187-202. [CrossRef]

111. Waldrip, B.; Yu, J.J.; Prain, V. Validation of a Model of Personalised Learning. Learn. Environ. Res. 2016, 19, 169-180. [CrossRef]

112. Schunk, D.H.; Zimmerman, B.J. Influencing Children's Self-Efficacy and Self-Regulation of Reading and Writing Through Modeling. Read. Writ. Q. 2007, 23, 7-25. [CrossRef]

113. Phobun, P.; Vicheanpanya, J. Adaptive Intelligent Tutoring Systems for E-Learning Systems. Procedia Soc. Behav. Sci. 2010, 2, 4064-4069. [CrossRef]

114. Oyelere, S.S.; Qushem, U.B.; Jauregui, V.C.; Akyar, Ö.Y.; Tomczyk, Ł.; Sanchez, G.; Munoz, D.; Motz, R. Blockchain Technology to Support Smart Learning and Inclusion: Pre-Service Teachers and Software Developers Viewpoints. In Trends and Innovations in Information Systems and Technologies; Rocha, Á., Adeli, H., Reis, L.P., Costanzo, S., Orovic, I., Moreira, F., Eds.; Advances in Intelligent Systems and Computing; Springer International Publishing: Cham, Switzerland, 2020; pp. $357-366$. 